\title{
TECHNO-ECONOMIC FEASIBILITY OF SOLAR POWERED DRIP IRRIGATION FOR TOMATO (SOLANUM LYCOPERSICUM)
}

\author{
G. PRASANNA ${ }^{1}$, G. MANOJ KUMAR ${ }^{2}$ \& B. LAXMAN ${ }^{3}$ \\ ${ }^{1,2}$ Department of Agricultural Engineering, CAE, Kandi, PJTSAU, India \\ ${ }^{3}$ Department of Agricultural Engineering, CAE, BAPATLA, India
}

\begin{abstract}
The field investigation was conducted during rabi 2016-2017 with Arka vikas variety of tomato to assess the economic feasibility of solar powered drip irrigation system. The experiment was conducted with eight treatments replicated thrice and was laid out in split plot design. The result showed that highest yield of tomato was obtained in 80 percent ETc using 1.6 lph dripper discharge rate than any other treatment. The lowest yield was obtained at 100 ETc with 4.0 lph dripper discharge rate. The highest net returns and B: C ratio was obtained in 80 percent ETc with a 1.6 lph discharge rate.

KEYWORDS: Economic Feasibility, Solar Power, Discharge Rate
\end{abstract}

Received: Aug 20, 2017; Accepted: Sep 05, 2017; Published: Sep 12, 2017; Paper Id.: IJCSEIERDOCT20174

\section{INTRODUCTION}

Recently the demand for water has been increased due to the increase in population and the availability of water has become more crucial. To meet the need of gradually growing demand of crop production, modernizing the irrigation services through existing resources is a challenge to researchers. Population growth, increasing water stress and climatic variability stresses of finding ways of getting more crop per drop to meet our food needs. Drip irrigation is one solution to this problem which is an irrigation method which minimizes the use of water and fertilizer by allowing water to drip slowly to the roots of plants, either onto the soil surface or directly onto the root zone due to which a large quantity of water is saved and also the fertilizer which comes to the plant with the water (Aniket and Sengupta, 2014).

The main limitation of irrigation pumping is the availability of power to the farmers. Hence, the farmers are looking for alternative source of power for irrigation pumping. Solar energy is the most abundant source of energy in the world. Solar power is an environmental friendly form of energy which is an answer to today's power crisis. The solar powered irrigation system can be a suitable alternative for farmers, in the present state of energy crisis in India (Shinde and Wandre 2015). Photovoltaic (PV) generation is an efficient approach for using the solar energy. Solar panels (an array of photovoltaic cells) are now extensively used, for running street lights, water heaters and to meet domestic loads. The cost of solar panels has been constantly decreasing, which encourages its usage in various sectors. One way of the applications of solar technology in agriculture sector, is for pumping irrigation water. The major restriction for use of PV systems, are the high market prices of photon capture devices, installation costs and low energy conversion efficiency of PV cells available in the market (Cuadros et al., 2004). The cost is mostly dependent on the size of the PV array area. Hence, it is necessary to choose the correct dimension of PV solar power installations, in order to make the cost of the installation 
profitable in a short time scale.

\section{MATERIALS AND METHOD}

The experiment was conducted during Rabi (October- February) season, of 2016-2017 at the College of Agriculture, PJTSAU, Hyderabad (17 $50^{\prime} \mathrm{N}$ latitude and $80^{\circ} 00^{\prime} \mathrm{E}$ longitude), with an altitude of $542.6 \mathrm{~m}$ above mean sea level (MSL). The soil type was sandy clay loam in texture and had $\mathrm{p}^{\mathrm{H}}$ of 7.54. The experiment was laid out using split plot statistical design, a total of eight treatments comprising of two main treatments (irrigation levels) and four sub treatments (dripper discharge rates) and the treatments were replicated thrice to reduce errors in readings. The treatment details are as follows.

$$
\begin{aligned}
& \text { Main treatments } \\
& \mathrm{I}_{1}=\text { Water application through drip at } 80 \text { percent ETc. } \\
& \mathrm{I}_{2}=\text { Water application through drip at } 100 \text { percent ETc. } \\
& \text { Sub treatments } \\
& \mathrm{D}_{1}=\text { Dripper discharge rate } 1.6 \mathrm{lph} \\
& \mathrm{D}_{2}=\text { Dripper discharge rate } 2.2 \mathrm{lph} \\
& \mathrm{D}_{3}=\text { Dripper discharge rate } 3.0 \mathrm{lph} \\
& \mathrm{D}_{4}=\text { Dripper discharge rate } 4.0 \mathrm{lph}
\end{aligned}
$$$$
\mathrm{I}_{2}=\text { Water application through drip at } 100 \text { percent ETc. }
$$

The experimental plot size was $3.6 \times 10 \mathrm{~m}$ and transplanting was done in a paired row with crop spacing of $0.4 \mathrm{x}$ $0.4 \mathrm{~m}$. The crop water requirement was calculated by pan evaporation method (USWB open pan evaporimeter). The irrigation treatments were imposed after transplanting and the total amount of water required for tomato for each treatment was calculated by adding up all the depth of water applied.

The economics of solar powered drip irrigation method was worked out, in terms of net returns and the benefit cost ratio. Total cost of solar powered drip irrigation system for crop production is the sum of fixed cost and variable cost. Fixed cost consists of depreciation, interest on capital investment, repair and maintenance cost. Depreciation was calculated by using straight method which is widely used and worked out as follows $\mathrm{D}=\mathrm{I}-\mathrm{S} / \mathrm{L}$, where $\mathrm{D}$ is Depreciation per annum (Rs.), I is Initial cost of the system (Rs.), S is salvaged value (10 percent of the initial cost, Rs.) and L is Economic life period, years.

For this reason, life of submersible solar pump system was taken as twenty years and PVC is considered as ten years. The rate of interest was considered as twelve percent of the initial cost as per the prevailing bank rates. The variable cost is the sum of input cost and operating cost. Operating cost is the amount which is actually paid by the cultivator in cash throughout the crop period carrying various agricultural operations.

\section{RESULTS AND DISCUSSIONS}

The determination of the Benefit-Cost ratio, the fixed cost, variable cost and net returns were calculated for solar powered drip irrigation with different discharge rates. The results are presented in Table 1 and 2, and depicted in Figure 1 and 2. 
The initial cost of installing the solar powered drip irrigation system for vegetable crops is high, but over a period of time the cost could be recovered and the benefits derived would be higher than any other irrigation. Even during the first year itself the solar powered drip irrigation system showed maximum net returns. The net returns and Benefit-Cost ratio is directly related to cost increases, and yield obtained in the treatment.

Cost of cultivation of the Rabi tomato, varied from 92,644.8 to 93,024.0 (Rs. ha ${ }^{-1}$ ), in different treatments. Gross returns from solar powered drip irrigated Rabi tomato, varied among different treatments and significantly higher (Rs.3, $12,135 \mathrm{ha}^{-1}$ ) gross returns were recorded with drip irrigation scheduled at 80 percent ETc with 1.6 lph discharge rate compared to all other treatments and lowest gross returns were recorded with 100 percent ETc in 4.0 lph discharge rate. Among the irrigation levels higher gross returns were obtained in 80 percent ETc compared to 100 percent ETc.

Table 1: Fixed Cost of Solar Powered Drip Irrigation System

\begin{tabular}{|c|l|c|}
\hline 1 & Initial investment (Rs.) & $5,66,796$ \\
\hline 2 & Depreciation (Rs per annum) & 25,505 \\
\hline 3 & Interest on investment @ 12\% (Rs. Per annum) & 68,015 \\
\hline 4 & Repair and maintenance costs (Rs. Per annum) & 5,667 \\
\hline 5 & Total fixed cost (Rs. Per annum) & 99,189 \\
\hline
\end{tabular}

Table 2: Economics of Solar Powered Drip Irrigation System with Different Discharge Rates at Different Irrigation Levels

\begin{tabular}{|c|c|c|c|c|c|}
\hline Treatments & $\begin{array}{c}\text { Total Cost of } \\
\text { Production }\left(\text { Rs. } \text { ha }^{-1}\right)\end{array}$ & $\begin{array}{l}\text { Yield } \\
\left(t \text { ha }^{-1}\right)\end{array}$ & $\begin{array}{l}\text { Gross Returns } \\
\left(\text { Rs. ha }{ }^{-1}\right)\end{array}$ & $\begin{array}{l}\text { Net Returns } \\
\left(\text { Rs.ha }^{-1}\right)\end{array}$ & $\begin{array}{l}\text { B: C } \\
\text { Ratio }\end{array}$ \\
\hline$\left(\mathrm{I}_{1} \mathrm{D}_{1}\right)$ & 92,644 & 20.809 & $3,12,135$ & 2,19490 & 2.37 \\
\hline$\left(\mathrm{I}_{2} \mathrm{D}_{2}\right)$ & 92,654 & 18.959 & $2,84,385$ & $1,9,1730$ & 2.07 \\
\hline$\left(\mathrm{I}_{3} \mathrm{D}_{3}\right)$ & 92,664 & 17.039 & $2,55,585$ & $1,62,920$ & 1.76 \\
\hline$\left(\mathrm{I}_{4} \mathrm{D}_{4}\right)$ & 92,664 & 15.769 & $2,36,535$ & $1,43,870$ & 1.55 \\
\hline$\left(\mathrm{I}_{5} \mathrm{D}_{5}\right)$ & 92,964 & 20.154 & $3,02,310$ & $2,09,346$ & 2.25 \\
\hline$\left(\mathrm{I}_{6} \mathrm{D}_{6}\right)$ & 92,984 & 18.104 & $2,71,560$ & $1,78,576$ & 1.92 \\
\hline$\left(\mathrm{I}_{7} \mathrm{D}_{7}\right)$ & 93,024 & 16.534 & $2,48,010$ & $1,54,986$ & 1.67 \\
\hline$\left(\mathrm{I}_{8} \mathrm{D}_{8}\right)$ & 93,024 & 14.804 & $2,22,060$ & $1,29,036$ & 1.39 \\
\hline
\end{tabular}

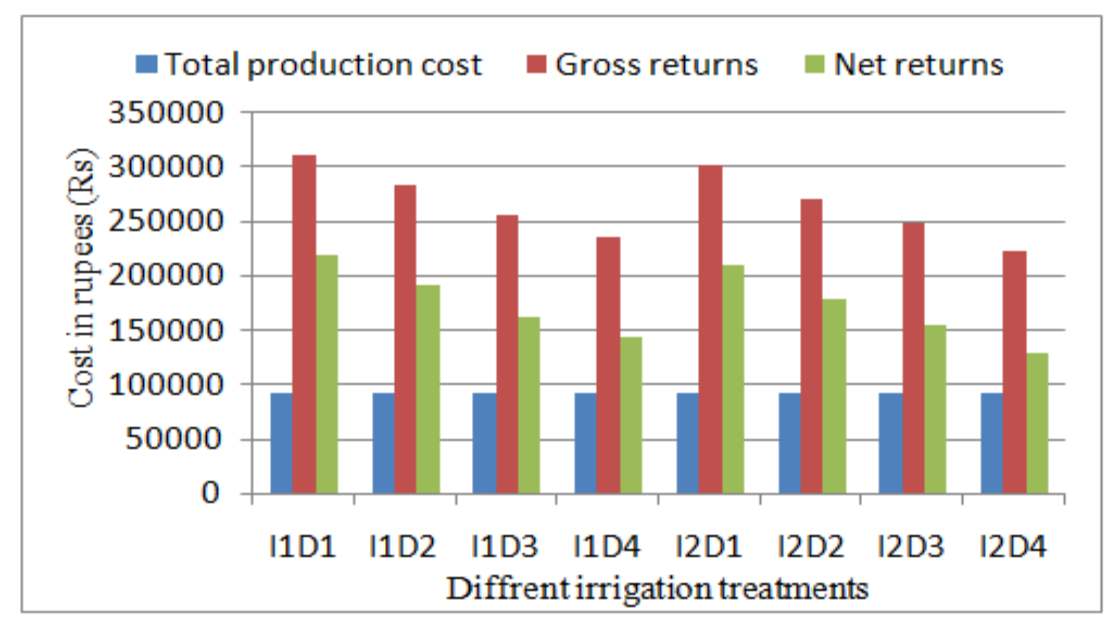

Figure 1: Economics of Tomato under Solar Powered Drip Irrigation as Influenced by Different Discharge Rate at Different Irrigation Levels

Net returns of Rabi tomato obtained from the treatment of irrigation at 80 percent ETc with 1.6 lph discharge rate followed by the treatment of 80 percent ETc with 2.2 lph discharge rate (Rs. 1,91,730 ha ${ }^{-1}$ ) and the lowest net return was 
obtained in 100 percent ETc (Rs.1, 29,036 ha ${ }^{-1}$ ) with a 4.0 lph discharge rate. The differences in net returns were due to the variations in tomato yield. The higher application rate resulted in more water application near crop root zone and the pores are filled water that might have resulted in less aeration and less nutrient uptake by root that consequently affected the growth.

Higher Benefit-Cost ratio of 2.37 was obtained from the irrigation treatment of 80 percent ETc with 1.6 lph discharge rate followed by 80 percent ETc with 2.2 lph discharge rate (2.07). The lowest Benefit-Cost ratio was recorded in 100 percent ETc (1.39) with a 4.0 lph discharge rate.

The higher net returns of tomato associated with higher yield, and lower cost of cultivation. A similar trend was also exhibited in terms of the Benefit - Cost ratio, which was highest in 80 percent ETc in combination with 1.6 lph discharge rate (2.37) followed by 80 percent ETc in combination with a 2.2 lph discharge rate.

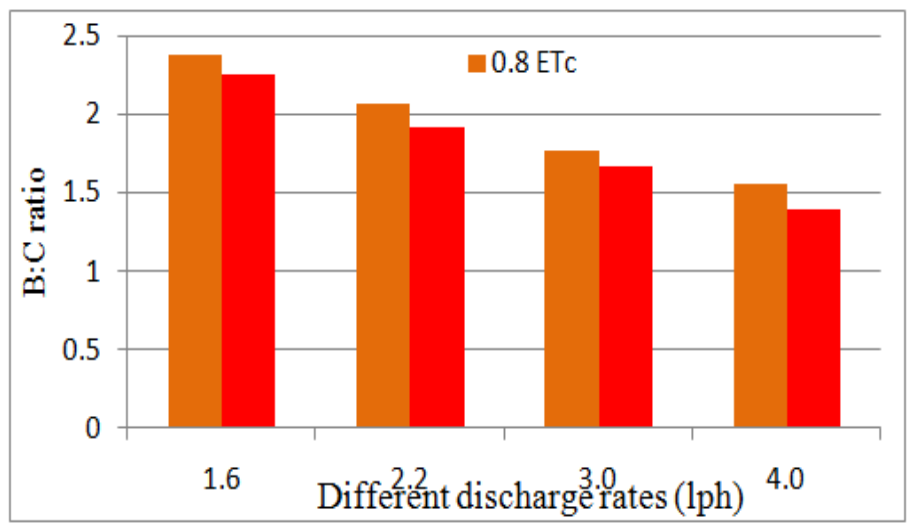

Figure 2: B: C Ratio of Tomato under Solar Powered Drip Irrigation as Influenced by Different Discharge Rate at Different Irrigation Levels

\section{CONCLUSIONS}

Growing of tomato was economically viable, under solar powered drip irrigation, as net returns (Rs.2, 19,490 ha ${ }^{-1}$ ) and B: C ratio (2.37) was significantly higher with drip irrigation scheduled at 80 percent ETc with 1.6 lph discharge rates and low (1.39) B: C ratio was recorded at 100 percent ETc with 4.0 lph discharge rates. The B: C ratio of solar powered drip irrigation system was recorded more than 1 in all the treatments and it can be concluded that the system is economically feasible.

\section{REFERENCES}

1. Aniket, H.H and Sengupta, M.K. 2014. Automatic control of drip irrigation system and monitoring of soil by wireless. ISOR Journal of Agriculture and Veterinary Science.Vol.7: 57-61.

2. Cuadros, F., Lopez-Rodriguez, F., Marcos, A., Coello, J. 2004. A procedure for solar-powered irrigation (photo-irrigation) schemes. Solar energy. 76(4): 465-473.

3. Hossain, M. A., Hassan, M.S., Ahmmed, S and Islam, M. S. 2014. Solar pump irrigation system for green agriculture. CIGR Journal. 16(4): $1-15$.

4. Mallikarjun Reddy, Ayyanagowadar, M. S., Nemicahndrappa, M., Balakrishnan, P., Patil, M. G and Satish Kumar, U. 2012. Techno economic feasibility of drip irrigation for anyone (Alluim cepa L.). Karnataka J. Agric. Sci. 25(4): 475-478. 
5. Satish, C., Avil Kumar, K., Praveen Rao, V., Umadevi, M and Sreenivas Kumar, K. 2016. Economics of Rabi Sorghum (Sorghum Bicolor (L.) Moench) As Influenced By Different Drip Irrigation Levels. International Journal of Agriculture Sciences. Vol 8:1622-1623.

6. Shinde, V. B and Wandre, S. S. 2015. Solar photovoltaic water pumping system for irrigation: a review. African Journal of Agricultural Research. 10 (22): 2267-2273 
